\title{
Genetic variability of Fusarium solani and Fusarium oxysporum f. sp. passiflorae isolates from Pantanal, Amazon and Cerrado biomes of Mato Grosso, Brazil
}

\author{
Arielen Barreto de Carvalho ${ }^{1}$, Valdomiro José Coelho ${ }^{1}$, Kelly Lana Araújo ${ }^{1}$, Kátia Aparecida \\ de Siqueira ${ }^{2}$, Sandra Mara Alves da Silva Neves ${ }^{1}$, Marcos Antônio Soares ${ }^{2}$ and \\ Leonarda Grillo Neves ${ }^{1 *}$ \\ ${ }^{1}$ Universidade do Estado de Mato Grosso (UNEMAT), Cáceres, MT, Brazil. \\ ${ }^{2}$ Universidade Federal de Mato Grosso (UFMT), Cuiabá, MT, Brazil.
}

Received 26 August, 2015; Accepted 3 November, 2015

\begin{abstract}
Soil fungi, Fusarium solani and Fusarium oxysporum f. sp. passiflorae are among the pathogens of greatest economic importance to the passion fruit culture. Little is known about the genetic variability of these pathogens from different regions. The genetic variability of $F$. solani and $F$. oxysporum $f$. sp. passiflorae isolates from Pantanal, Amazon and Cerrado of Mato Grosso State, Brazil, was studied with the help of molecular markers inter-simple sequence repeat amplification (ISSR) and interretrotransposon amplified polymorphism (IRAP). The molecular identification of the isolates was performed by partial sequencing of the internal transcribed spacer (ITS) of the rDNA region. High genetic variability among isolates of $F$. solani and $F$. oxysporum $f$. sp. passiflorae was found. The dendrogram generated by UPGMA divided the fungi isolates in two large groups, however, with grouping tendency according to the biome of collection only for $F$. oxysporum $\mathrm{f}$. sp. passiflorae. There was no significant correlation between geographic distance and genetic similarity for $F$. oxysporum $f$. sp. passiflorae and $F$. solani.
\end{abstract}

Key words: Collar rot, Fusarium wilt, passionflower, Passiflora edulis, inter-simple sequence repeat amplification (ISSR), inter-retrotransposon amplified polymorphism (IRAP).

\section{INTRODUCTION}

The Mato Grosso state houses three biomes: Pantanal, Cerrado and Amazon (IBGE, 2004). The Pantanal is a sedimentary plain with low topographic gradient and slow runoff water, characterized by seasonally flooded areas in the months of summer and fall (Assine, 2003; Junk et al., 2006). The climate in the Pantanal is hot and has two distinct seasons: rainy summer, from October to April, and dry winter, from May to September (Junk et al.,

*Corresponding author. E-mail: leonardaneves@unemat.br.

Author(s) agree that this article remain permanently open access under the terms of the Creative Commons Attribution License 4.0 International License 
2006). The Cerrado is the second largest Brazilian biome, characterized by formation of tropical savanna (IBGE, 2004), with prevailing tropical climate, with hot and humid summer and dry winter (Marcuzzo et al., 2011).

Currently, in Mato Grosso Cerrado, there is prevalence of beef cattle and intensive agriculture, especially the large plantations of soy, corn, beans, cotton, coffee and sugarcane (CONAB, 2015). The Amazon biome, the largest in the country with about 4.1 million $\mathrm{km}^{2}$, is mainly composed of three forest types: upland forests, lowland forests, periodically flooded by the rivers, and the Igapó forests, located near the riverbeds. In addition, this biome encompasses areas of savannas (Cerrado) and meadows (IBGE, 2004).

Brazil is the world's largest producer of passion fruit (Passiflora edulis Sims) with 838,000 tons in the 2013 crop, being Bahia $(355,020$ t) and Ceará $(213,902$ t), the largest Brazilian producers. In Mato Grosso, passion fruit production is still low, accounting for only $0.92 \%$ of the Brazilian production (IBGE, 2015). The occurrence of diseases is a major factor limiting the expansion of the cultivated area and the increasing passion fruit productivity in the state. Among the diseases that affect the passionflower, it is highlighted the collar rot, caused by the Fusarium solani fungus, anamorphic phase of Haematonectria haematococca (Berkeley and Broome) Samuels \& Nirenberg (Leslie and Summerell, 2006), and the Fusarium wilt, caused by the Fusarium oxysporum f. sp. passiflorae fungus (Fischer et al., 2005).

Fusarium wilt and collar rot are widespread in the main producing areas of passion fruit in Brazil. In regions with incidence of these diseases, the impact on passion fruit culture is significant, with reduced productivity, premature death of plants and consequently decrease in the life cycle of the orchards (Pio-Ribeiro and Mariano, 1997; Liberato and Costa, 2001; Fischer et al., 2005).

Furthermore, F. solani and F. oxysporum f. sp. passiflorae produce resistance structures, the chlamydospores (Leslie and Summerell, 2006), which allow its survival in the soil for several years, even without the presence of passion fruit (Pio-Ribeiro and Mariano, 1997; Fischer et al., 2005).

To prevent the damage caused by Fusarium wilt and collar rot, it is important to use preventive measures such as, avoid planting seedlings from places with occurrence history of these diseases (Fischer et al., 2005). In areas already infested, the use of resistant cultivars is one of the most important measures within the integrated management of Fusarium wilt and collar rot. In this context, the study of genetic variability of $F$. solani and $F$. oxysporum f. sp. passiflorae fungi is fundamental to direct passionflower genetic improvement programs in order to obtain resistant cultivars (Silva et al., 2013).

However, little information is available so far on the genetic variability of isolates of $F$. solani and $F$. oxysporum f. sp. passiflorae fungi collected from different regions (Silva et al., 2013).

Molecular markers, inter-simple sequence repeat amplification (ISSR) and inter-retrotransposon amplified polymorphism (IRAP) are used to determine the genetic variability in fungal species (Queiroz et al., 2014; Dinolfo et al., 2014; Saxena et al., 2014). Thus, the objective of this study was to evaluate the genetic variability of isolates of $F$. solani and $F$. oxysporum f. sp. passiflorae originating from Pantanal, Cerrado and Amazon biomes in the state of Mato Grosso, Brazil, through molecular markers ISSR and IRAP.

\section{MATERIALS AND METHODS}

\section{Fungi isolation}

Plants of yellow passion fruit showing typical symptoms of Fusarium wilt and collar rot were collected from the three areas of Mato Grosso biomes: Pantanal, Cerrado and Amazon. For the isolation of $F$. oxysporum f. sp. passiflorae and F. solani, small segments of symptomatic tissue from each sample collected were superficially disinfected with $70 \%$ alcohol and $1 \%$ sodium hypochlorite, and then washed in sterilized distilled water.

Thereafter, the segments were transferred to Petri dishes containing the agar culture PCNB (Nash and Snyder, 1962). The plates were incubated in $\mathrm{BOD}$, with temperature of $24^{\circ} \mathrm{C}$ and $12 \mathrm{~h}$ photoperiod for colony growth. Morphological characterization of the isolates was made after the isolation processes, based on color of the colony; presence or absence, size and format of macro and microconidia; presence or absence and arrangement of chlamydospores; and the type of phialides where conidia are formed (Nelson et al., 1983; Nirenberg, 1990). After the morphological characterization and the species identification, monosporic cultures of each isolate were prepared. Then, the monosporic isolates were stored in the Mycology Collection of the Vegetable Breeding Laboratory from the University of Mato Grosso (UNEMAT), Cáceres campus.

\section{Formulation of thematic map}

Cartographic representations concerning areas with occurrence of Fusarium wilt and collar rot - where plants of yellow passion fruit showing typical symptoms were collected from the three areas of Mato Grosso biomes - were delimited in the field, along with the owner, using GPS navigation. These data from the field work were used in the preparation of layouts of thematic maps. To make the respective thematic maps, the data recorded in the GPS (points and tracks) were discharged through TrackMaker and MapSource software. In sequence, these were imported into ArcGIS software, version 9.2, Esri, for editing, thus building the geographical database of research.

\section{DNA extraction of isolates and analysis of genetic variability}

For the extraction of genomic DNA, the monosporic isolates of $F$. solani and $F$. oxysporum f. sp. passiflorae were grown in liquid potato dextrose agar (PDA) medium for two weeks. Subsequently, the mycelium was macerated in liquid nitrogen. DNA extraction was performed using extraction kit (Axygen Biosciences USA) according to the manufacturer.

Validation of morphotyping was determined with the help of molecular markers ISSR and IRAP. The primers used in this study 
Table 1. Primers used in the analysis of IRAP and ISSR markers (Longato and Bonfante, 1997; Santos et al., 2012).

\begin{tabular}{lll}
\hline Marker & Identifier & Sequence 5' - 3' \\
\hline ISSR & BH1 & GTG GTG GTG GTG GTG \\
IRAP & CI IRAP1 & CGTACGGAACACGCTACAGA \\
& CI IRAP4 & CTTTTGACGAGG CCATGC \\
\hline
\end{tabular}

are shown in Table 1. The volume of $25 \mu \mathrm{l}$ reaction mixture and the PCR program were the same for both markers. In each sample, it was used approximately $60 \mathrm{ng}$ of total DNA, $2.5 \mu \mathrm{l}$ of $10 \times$ PCR buffer, $2.5 \mathrm{mM}$ of each dNTP, $10 \mathrm{pMol}$ of the oligo, $1 \mathrm{U}$ of Taq polymerase and ultrapure $\mathrm{H}_{2} \mathrm{O}$ s.q.f. to $25 \mu \mathrm{L}$. The program consisted of an initial denaturation step at $94^{\circ} \mathrm{C}$ for 2 min, followed by 35 cycles of $94^{\circ} \mathrm{C}$ for $1 \mathrm{~min}, 50^{\circ} \mathrm{C}$ for $2 \mathrm{~min}$ and $72^{\circ} \mathrm{C}$ for $2 \mathrm{~min}$, and a final step of elongation at $72^{\circ} \mathrm{C}$ for $10 \mathrm{~min}$ in Amplitherm Thermal cycles thermocycler. Products from PCR were subjected to agarose gel electrophoresis, $1.6 \%$. The sizes of the amplified ones were determined with the 123 bp DNA Ladder marker (SigmaAldrich, Inc.) and $1 \mathrm{~kb}$ DNA Ladder (BioLabs).

In the evaluation of the gels, the presence (1) and absence (0) of bands were used for the construction of two binary matrices, one for $F$. solani and one for F. oxysporum f. sp. passiflorae. Binary arrays were used for the calculation of genetic similarities employing the Jaccard coefficient (Jaccard, 1908). Then UPGMA cluster analysis was done for the preparation of dendrograms. Cluster analysis was obtained by the data generated by the combination of molecular markers ISSR and IRAP. All calculations of dissimilarity and construction of dendrogram were made with the aid of NTSYSpc 2.10 program.

With the data of the genetic and geographic distances, Mantel's test was performed, using the program Genes (Cruz, 2006), to assess the correlation between the spatial distance matrix and the genetic distance. 10,000 simulations were used to test the significance of the matrix correlations.

\section{Molecular identification of the isolates}

The molecular identification of the isolates was performed by partial sequencing of the internal transcribed spacer (ITS) of the rDNA region. The primers ITS4 (5'-TCCTCCGCTTATTGATATGC-3') and ITS5 (GGAAGTAAAAGTCGTAACAAGG 5'-3') were used for amplification of the rDNA ITS region (White et al., 1990). For $25 \mu \mathrm{L}$ reaction, approximately $60 \mathrm{ng}$ of total DNA, $2.5 \mu \mathrm{l}$ of $10 \mathrm{x}$ PCR buffer, $2.5 \mathrm{mM}$ of each dNTP, 10 pMol of each primer oligonucleotide, $1 \mathrm{U}$ of Taq polymerase and ultrapure $\mathrm{H}_{2} \mathrm{O}$ s.q.f. to $25 \mu \mathrm{L}$ were used. The program consisted of an initial denaturation step at $94^{\circ} \mathrm{C}$ for $2 \mathrm{~min}$, followed by 35 cycles of $94^{\circ} \mathrm{C}$ for $45 \mathrm{~s}, 50^{\circ} \mathrm{C}$ for $45 \mathrm{~s}$, and $72^{\circ} \mathrm{C}$ for $1 \mathrm{~min}$, and a final step of elongation at $72^{\circ} \mathrm{C}$ for 10 min in Amplitherm Thermal cycles thermocycler. Sequencing was performed by the Sanger method with the Big Dye Kit in ABI3100 Applied Biosystem sequencer (Dunn and Blattner, 1987). The sequences were compared with existing sequences in GenBank database using the BLAST program available at National Center for Biotechnology Information - www.ncbi.nlm.nih.gov (NCBI site).

\section{RESULTS AND DISCUSSION}

The location of collection of yellow passion fruit plants showing typical symptoms of Fusarium wilt (FW) and collar rot (CR) in the Mato Grosso biomes Amazon, Pantanal and Cerrado is represented on the map in Figure 1. Over half of the total area of Mato Grosso State $(54 \%)$ is occupied by the Amazon biome. The Cerrado is the second largest biome of the state, occupying $39 \%$ of the area, and the Pantanal biome represents only $7 \%$ of the total area of the state (IBGE, 2004).

A total of twenty isolates of $F$. solani were obtained, being nine from the Amazon biome, eight from Cerrado and three from Pantanal (Table 2). With respect to $F$. oxysporum f. sp. passiflorae, ten isolates were obtained, seven from the Amazon biome and three from Cerrado. Only one isolate of $F$. oxysporum f. sp. passiflorae was isolated from the Pantanal biome (Table 2). The lower number of isolates found in the Pantanal can be explained by the low density of human occupation in this biome, with livestock prudution being the main economic activity (Gavlak et al., 2013). Also, as passionflower is a semi-perennial crop, with economic production cycle of about three years (Bruckner and Picanço, 2001), seasonal flooding of most of the Pantanal (Junk et al., 2006) make the economic cultivation of passion fruit in these areas impossible.

The genetic similarity obtained by the Jaccard coefficients ranged from 0.00 to 0.38 for $F$. oxysporum f. sp. passiflorae, and are shown in Table 3. Maximum similarity was observed between $7 \mathrm{~A}$ and $17 \mathrm{~A}$ isolates from, respectively, São José dos IV Marcos and Paranaíba, both collection points belonging to the Amazon biome (Table 3). The maximum genetic dissimilarity was between the isolates $3 \mathrm{~A}$, from São José dos IV Marcos (Amazon biome), and 1C, from Cáceres (Cerrado biome) (Table 2). Silva et al. (2013), working with 14 isolates of $F$. oxysporum f. sp. passiflorae from Bahia (BR) and one isolate collected in Minas Gerais (BR), also observed genetic variability among isolates. As mating in $F$. oxysporum has not yet been reported (Leslie and Summerell, 2006), the generation of variability in this species can be related to different events, such as mutation and parasexual reproduction (Huang et al., 2013; Silva et al., 2013), and environmental factors of the geographic region where the pathogen is located (Silva et al., 2013). The transposable elements constitute a source of mutations likely to be a major cause of genetic variability of $F$. oxysporum (Daboussi and Langin, 1994; Schmidt et al., 2013).

This study showed that for the $F$. solani, the genetic similarity ranged from 0.00 to 0.56 , indicating high genetic variability among isolates. The highest similarity was identified between $5 \mathrm{~A}$ and $8 \mathrm{~A}$ pairs, and the smaller among $5 \mathrm{C}$ and $11 \mathrm{~A}$ isolates, in addition to the pair $7 \mathrm{C}$ and $16 \mathrm{C}$ (Table 4). Isolates $5 \mathrm{~A}$ and $8 \mathrm{~A}$ were from the city of São José dos IV Marcos and isolate 11A was collected in Carlinda. These three isolates were from the Amazon biome (Table 2). Isolates $7 \mathrm{C}$ and $16 \mathrm{C}$ were collected in the Cerrado biome (Table 2). This high genetic variability found between $F$. solani isolates may be associated with 


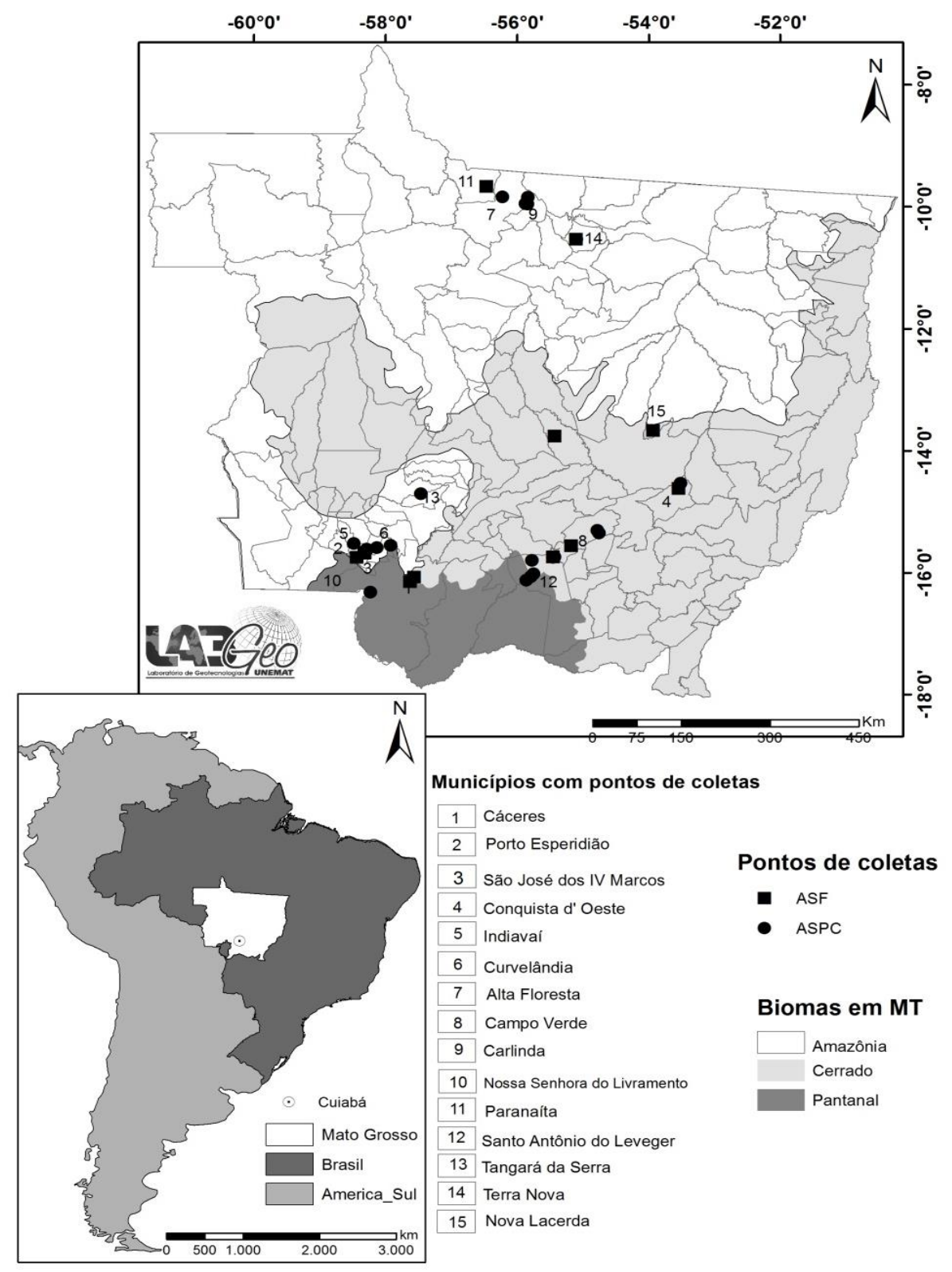

Figure 1. Map of Mato Grosso State showing the three biomes (Amazon, Cerrado and Pantanal) and collection points of passion fruit plants presenting symptoms of Fusarium wilt (FW or ASF) and collar rot (CR or ASPC).

sexual and parasexual cycles, and with mutations (Waalwijk et al., 2006; Dufresne et al., 2011). In the F. solani species, sexual reproduction is common (Leslie and Summerell, 2006), and in passion fruit it is characterized by the formation of reddish perithecia on the injured lap of the plant (Fischer et al., 2005).

Analyzing the dendrogram generated by the genetic similarity matrix among the 10 isolates of $F$. oxysporum $\mathrm{f}$. sp. passiflorae generated by UPGMA method, it was possible to observe the formation of two large groups, I and II, with two subgroups in each group (Figure 2). In group I, only the isolates from the Amazon biome were grouped, being the subgroup $\mathrm{I} .1$ formed by isolates $2 \mathrm{~A}$ and $16 \mathrm{~A}$, and the subgroup I.2 formed by isolates $7 \mathrm{~A}$ and 17A. In group II, isolates from two biomes were grouped, notwithstanding, the ones collected in the Cerrado biome (1C, 2C and 4C) were grouped only in subgroup II.2. In the II.1 subgroup, the other three isolates from the Amazon biome were grouped (3A, 4A and 10A). The existence of a relationship between genetic similarity and the biomes of collection of $F$. oxysporum f. sp. passiflorae isolates may be an indication of the influence of 
Table 2. List of isolates of $F$. oxysporum f. sp. passiflorae and $F$. solani used in the study and their origin.

\begin{tabular}{|c|c|c|c|}
\hline Biome & Isolate & Species & Location \\
\hline \multirow{16}{*}{ Amazon } & $1 \mathrm{~A}$ & F. solani & São José dos IV Marcos \\
\hline & $2 A$ & F. oxysporum f. sp. passiflorae & São José dos IV Marcos \\
\hline & $3 A$ & F. oxysporum f. sp. passiflorae & São José dos IV Marcos \\
\hline & $4 \mathrm{~A}$ & F. oxysporum f. sp. passiflorae & São José dos IV Marcos \\
\hline & $5 A$ & F. solani & São José dos IV Marcos \\
\hline & $6 \mathrm{~A}$ & F. solani & Indiavaí \\
\hline & $7 A$ & F. oxysporum f. sp. passiflorae & São José dos IV Marcos \\
\hline & $8 \mathrm{~A}$ & F. solani & São José dos IV Marcos \\
\hline & $10 \mathrm{~A}$ & F. oxysporum f. sp. passiflorae & Porto Esperidião \\
\hline & $11 \mathrm{~A}$ & F. solani & Carlinda \\
\hline & $12 \mathrm{~A}$ & F. solani & Carlinda \\
\hline & $15 \mathrm{~A}$ & F. solani & Alta Floresta \\
\hline & $16 \mathrm{~A}$ & F. oxysporum f. sp. passiflorae & Terra Nova \\
\hline & $17 \mathrm{~A}$ & F. oxysporum f. sp. passiflorae & Paranaíba \\
\hline & $18 \mathrm{~A}$ & F. solani & Carlinda \\
\hline & $19 \mathrm{~A}$ & F. solani & Terra Nova \\
\hline \multirow{13}{*}{ Cerrado } & $1 \mathrm{C}$ & F. oxysporum f. sp. passiflorae & Cáceres \\
\hline & $2 \mathrm{C}$ & F. oxysporum f. sp. passiflorae & Nova Lacerda \\
\hline & $3 C$ & F. solani & Conquista d'Oeste \\
\hline & $4 \mathrm{C}$ & F. oxysporum f. sp. passiflorae & Conquista d'Oeste \\
\hline & $5 \mathrm{C}$ & F. solani & Tangará da Serra \\
\hline & $6 \mathrm{C}$ & F. solani & Santo Antônio de Leverger \\
\hline & $7 \mathrm{C}$ & F. solani & Santo Antônio de Leverger \\
\hline & $9 \mathrm{C}$ & F. solani & Campo Verde \\
\hline & $10 \mathrm{C}$ & F. oxysporum f. sp. passiflorae & Campo Verde \\
\hline & $15 \mathrm{C}$ & F. solani & Santo Antônio de Leverger \\
\hline & $12 \mathrm{C}$ & F. oxysporum f. sp. passiflorae & Campo Verde \\
\hline & $16 \mathrm{C}$ & F. solani & Campo Verde \\
\hline & $18 \mathrm{C}$ & F. solani & Campo Verde \\
\hline \multirow{5}{*}{ Pantanal } & $1 \mathrm{P}$ & F. oxysporum f. sp. passiflorae & Cáceres \\
\hline & $2 \mathrm{P}$ & F. solani & Curvelândia \\
\hline & 3P & F. solani & Nossa Senhora do Livramento \\
\hline & $4 \mathrm{P}$ & F. solani & Santo Antônio de Leveger \\
\hline & $5 \mathrm{P}$ & F. solani & Santo Antônio de Leveger \\
\hline
\end{tabular}

environmental factors of the geographical location area on pathogen variability mechanisms (Silva et al., 2013).

Through analysis of the dendrogram generated by genetic similarity matrix among $20 \mathrm{~F}$. solani isolates, one can find the formation of two major groups, I and II, with two subgroups in each group (Figure 3). There was no relationship between genetic similarity and geographic region of collection, where isolates from each biome were divided into different subgroups. In the subgroup I.1 A, isolates $1 \mathrm{~A}$ and $19 \mathrm{~A}$, from the Amazon biome, and $15 \mathrm{C}$ and $16 \mathrm{C}$, collected in the Cerrado biome, were grouped. Isolates $5 \mathrm{~A}, 8 \mathrm{~A}, 12 \mathrm{~A}, 15 \mathrm{~A}, 18 \mathrm{~A}$ and $6 \mathrm{~A}$, collected in the Amazon, were grouped in subgroup I.2, along with isolated $18 \mathrm{C}$ and $5 \mathrm{C}$, belonging to the Cerrado biome. The II.1 subgroup consisted of isolates from the three biomes, being 11A (Amazon biome), 3P (Pantanal biome) and isolates $3 \mathrm{C}, 6 \mathrm{C}, 7 \mathrm{C}$ and $9 \mathrm{C}$ from the Cerrado biome. In II.2 subgroup, only isolates from the Cerrado biome (4P and 5P) were grouped. The non-grouping of isolates as to geographical location corroborates with reports in the literature for $F$. solani in other pathosystems (Arruda et al., 2005; Brasileiro et al., 2004).

There was no significant correlation, by Mantel test, between geographic distance and genetic similarity to $F$. oxysporum f. sp. passiflorae $(r=0.015, t=0.0765 ; p=$ 
Table 3. Genetic similarity measures $\left(\mathrm{D}^{2}\right)$ between pairs of isolates of $F$. oxysporum f. sp. Passiflorae.

\begin{tabular}{|c|c|c|c|c|c|c|c|c|c|c|}
\hline & 2A & $3 A$ & $4 \mathrm{~A}$ & $7 \mathrm{~A}$ & $10 \mathrm{~A}$ & $16 \mathrm{~A}$ & $17 \mathrm{~A}$ & $1 \mathrm{C}$ & $2 \mathrm{C}$ & 4C \\
\hline $2 A$ & 1.00 & & & & & & & & & \\
\hline $3 A$ & 0.07 & 1.00 & & & & & & & & \\
\hline $4 \mathrm{~A}$ & 0.15 & 0.23 & 1.00 & & & & & & & \\
\hline $7 A$ & 0.15 & 0.18 & 0.16 & 1.00 & & & & & & \\
\hline $10 \mathrm{~A}$ & 0.13 & 0.26 & 0.31 & 0.10 & 1.00 & & & & & \\
\hline $16 \mathrm{~A}$ & 0.22 & 0.20 & 0.10 & 0.17 & 0.14 & 1.00 & & & & \\
\hline $17 \mathrm{~A}$ & 0.16 & 0.06 & 0.17 & 0.38 & 0.08 & 0.10 & 1.00 & & & \\
\hline $1 \mathrm{C}$ & 0.06 & 0.00 & 0.19 & 0.08 & 0.15 & 0.10 & 0.14 & 1.00 & & \\
\hline $2 \mathrm{C}$ & 0.09 & 0.10 & 0.20 & 0.15 & 0.13 & 0.08 & 0.16 & 0.27 & 1.00 & \\
\hline $4 C$ & 0.15 & 0.08 & 0.16 & 0.09 & 0.16 & 0.13 & 0.13 & 0.30 & 0.19 & 1.00 \\
\hline
\end{tabular}

Table 4. Genetic similarity measures $\left(D^{2}\right)$ between pairs of isolates of $F$. solani.

\begin{tabular}{|c|c|c|c|c|c|c|c|c|c|c|c|c|c|c|c|c|c|c|c|c|}
\hline & $1 \mathrm{~A}$ & $5 \mathrm{~A}$ & $6 \mathrm{~A}$ & $8 \mathrm{~A}$ & $11 \mathrm{~A}$ & $12 \mathrm{~A}$ & $15 \mathrm{~A}$ & $18 \mathrm{~A}$ & 19A & $3 C$ & $5 \mathrm{C}$ & $6 C$ & $7 \mathrm{C}$ & $9 \mathrm{C}$ & $15 \mathrm{C}$ & $16 \mathrm{C}$ & $18 \mathrm{C}$ & $3 P$ & $4 P$ & $5 P$ \\
\hline $1 \mathrm{~A}$ & 1.00 & & & & & & & & & & & & & & & & & & & \\
\hline $5 A$ & 0.12 & 1.00 & & & & & & & & & & & & & & & & & & \\
\hline $6 A$ & 0.19 & 0.27 & 1.00 & & & & & & & & & & & & & & & & & \\
\hline $8 \mathrm{~A}$ & 0.14 & 0.56 & 0.29 & 1.00 & & & & & & & & & & & & & & & & \\
\hline $11 \mathrm{~A}$ & 0.21 & 0.15 & 0.16 & 0.14 & 1.00 & & & & & & & & & & & & & & & \\
\hline $12 \mathrm{~A}$ & 0.10 & 0.37 & 0.27 & 0.38 & 0.26 & 1.00 & & & & & & & & & & & & & & \\
\hline $15 \mathrm{~A}$ & 0.19 & 0.32 & 0.27 & 0.33 & 0.16 & 0.44 & 1.00 & & & & & & & & & & & & & \\
\hline $18 \mathrm{~A}$ & 0.15 & 0.25 & 0.31 & 0.26 & 0.27 & 0.35 & 0.47 & 1.00 & & & & & & & & & & & & \\
\hline $19 A$ & 0.18 & 0.15 & 0.06 & 0.13 & 0.18 & 0.16 & 0.20 & 0.29 & 1.00 & & & & & & & & & & & \\
\hline $3 C$ & 0.20 & 0.08 & 0.21 & 0.13 & 0.31 & 0.22 & 0.18 & 0.32 & 0.13 & 1.00 & & & & & & & & & & \\
\hline $5 C$ & 0.21 & 0.19 & 0.19 & 0.17 & 0.00 & 0.12 & 0.23 & 0.14 & 0.08 & 0.06 & 1.00 & & & & & & & & & \\
\hline $6 C$ & 0.10 & 0.07 & 0.09 & 0.06 & 0.14 & 0.13 & 0.09 & 0.18 & 0.08 & 0.25 & 0.13 & 1.00 & & & & & & & & \\
\hline $7 C$ & 0.10 & 0.11 & 0.13 & 0.06 & 0.10 & 0.17 & 0.17 & 0.15 & 0.09 & 0.21 & 0.24 & 0.39 & 1.00 & & & & & & & \\
\hline $9 \mathrm{C}$ & 0.14 & 0.11 & 0.19 & 0.17 & 0.14 & 0.06 & 0.20 & 0.21 & 0.08 & 0.25 & 0.23 & 0.37 & 0.32 & 1.00 & & & & & & \\
\hline $15 C$ & 0.26 & 0.19 & 0.12 & 0.13 & 0.17 & 0.32 & 0.28 & 0.14 & 0.17 & 0.20 & 0.17 & 0.08 & 0.08 & 0.13 & 1.00 & & & & & \\
\hline $16 \mathrm{C}$ & 0.21 & 0.13 & 0.14 & 0.15 & 0.04 & 0.10 & 0.14 & 0.16 & 0.22 & 0.11 & 0.21 & 0.05 & 0.00 & 0.22 & 0.21 & 1.00 & & & & \\
\hline $18 \mathrm{C}$ & 0.19 & 0.21 & 0.32 & 0.27 & 0.09 & 0.11 & 0.25 & 0.26 & 0.07 & 0.18 & 0.19 & 0.11 & 0.07 & 0.25 & 0.11 & 0.18 & 1.00 & & & \\
\hline $3 P$ & 0.29 & 0.09 & 0.13 & 0.08 & 0.21 & 0.08 & 0.26 & 0.27 & 0.27 & 0.35 & 0.13 & 0.27 & 0.19 & 0.32 & 0.13 & 0.12 & 0.16 & 1.00 & & \\
\hline $4 \mathrm{P}$ & 0.09 & 0.06 & 0.08 & 0.03 & 0.23 & 0.11 & 0.08 & 0.18 & 0.15 & 0.11 & 0.10 & 0.19 & 0.15 & 0.24 & 0.10 & 0.08 & 0.06 & 0.23 & 1.00 & \\
\hline $5 P$ & 0.10 & 0.03 & 0.06 & 0.03 & 0.14 & 0.17 & 0.09 & 0.08 & 0.09 & 0.10 & 0.13 & 0.25 & 0.20 & 0.19 & 0.18 & 0.11 & 0.04 & 0.10 & 0.43 & 1.00 \\
\hline
\end{tabular}




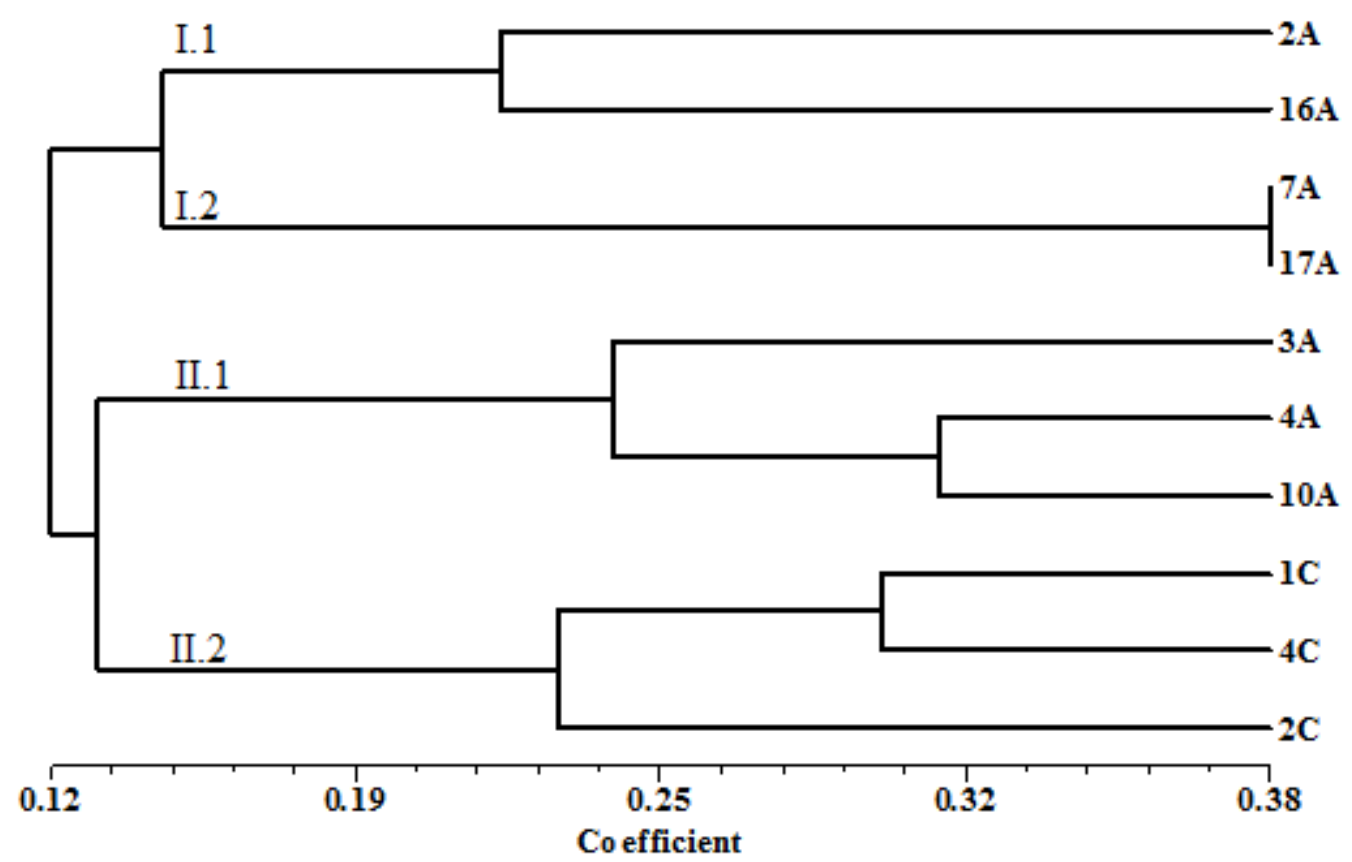

Figure 2. Dendrogram of genetic similarity among the 10 isolates of $F$. oxysporum $\mathrm{f}$. sp. passiflorae generated by the UPGMA method, using the Jaccard coefficients.

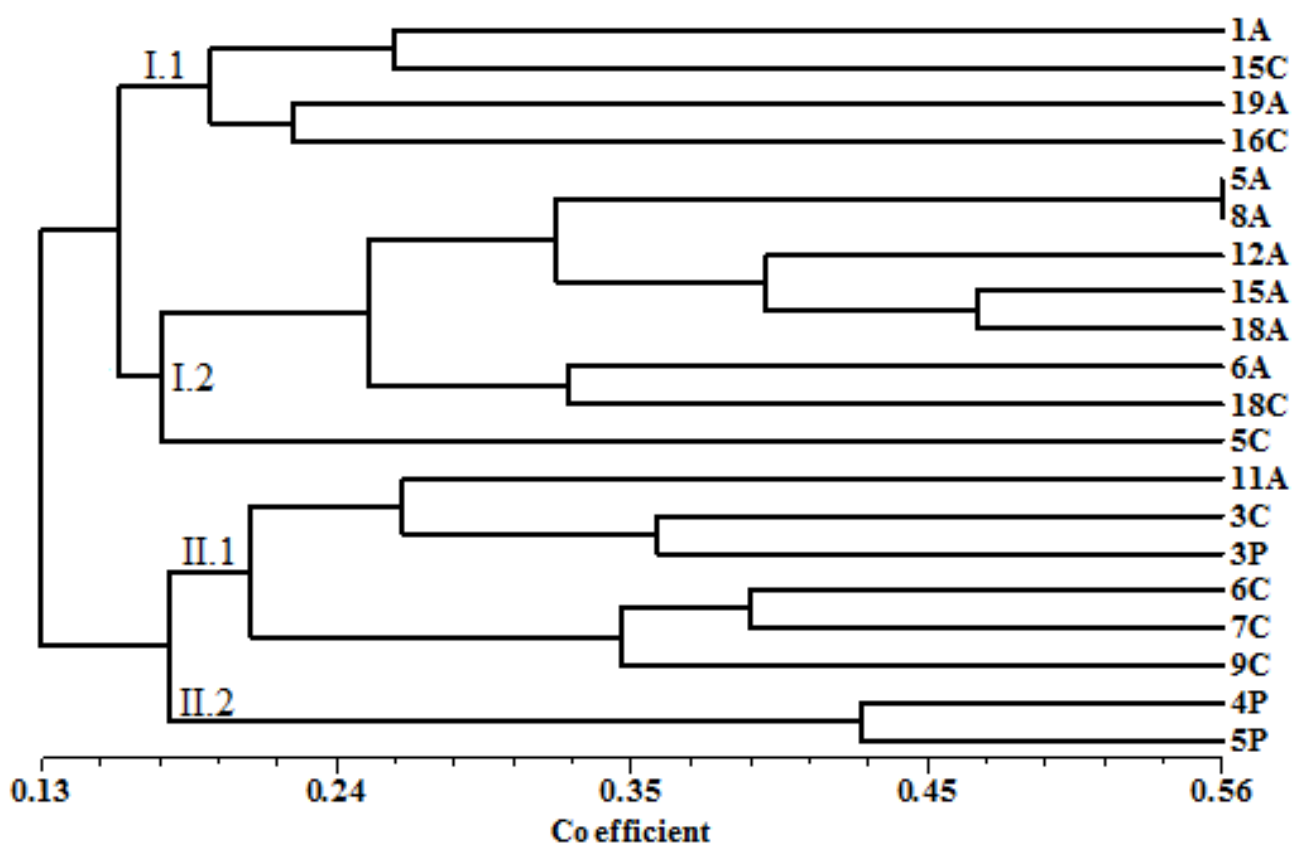

Figure 3. Dendrogram of genetic similarity among the 20 isolates of $F$. solani generated by the UPGMA method, using the Jaccard coefficients.

93.76) and Fusarium solani $(\mathrm{r}=-0.00246, \mathrm{t}=-0.03368 ; \mathrm{p}$ $=97.16 \%$ ). This lack of correlation can be attributed to small geographic distances between the sampled municipalities and to the exchange of infected material between the producers of passion fruit.

The high genetic variability presented by the isolates of $F$. oxysporum f. sp. passiflorae and F. solani is presented as an important frontier in obtaining passion fruit cultivars 
with durable resistance to Fusarium wilt and collar rot. However, further studies are needed to group these isolates also according to the virulence and aggressiveness.

\section{Conclusions}

1. The use of molecular markers ISSR and IRAP made it possible to detect high genetic variability in $F$. oxysporum f. sp. passiflorae and Fusarium solani collected in the Pantanal, Cerrado and Amazon biomes in the state of Mato Grosso, Brazil.

2. There was grouping tendency according to the biome of collection only for $F$. oxysporum f. sp. passiflorae fungus.

3. There was no significant correlation between geographic distance and genetic similarity for $F$. oxysporum f. sp. passiflorae and Fusarium solani.

\section{Conflict of Interests}

The authors have not declared any conflict of interests.

\section{REFERENCES}

Assine ML (2003). Sedimentação na bacia do pantanal matogrossense, centro oeste do Brasil. Habilitation Thesis. Universidade Estadual Paulista, Rio Claro. 105 p.

Arruda GMT, Miller RNG, Ferreira MASV, Cafe-Filho AC (2005). Morphological and molecular characterization of the sudden-death syndrome pathogen of soybean in Brazil. Plant Pathol. 54(1):53-65.

Brasileiro BTRV, Coimbra MRM, Morais-Junior MA, Oliveira NT (2004). Genetic variability within Fusarium solani species as revealed by PCR-fingerprinting based on PCR markers. Braz. J. Microbiol. 35(3):205-210.

Bruckner CH, Picanço MC (2001). Maracujá: tecnologia de produção, pós-colheita, agroindústria, mercado. $2^{\mathrm{a}}$ ed., Porto Alegre: Cinco Continentes. 472 p.

Huang CH, Roberts PD, Gale LR, Elmer WH, Datnoff LE (2013). Population structure of Fusarium oxysporum f. sp. radicis-lycopersici in Florida inferred from vegetative compatibility groups and microsatellites. Eur. J. Plant Pathol. 136(3):509-521.

CONAB - Companhia Nacional de Abastecimento (2015). Levantamentos de Safra. Available at: http://www.conab.gov.br.

Cruz CD (2006). Programa GENES: biometria. Viçosa: UFV. 382 p.

Daboussi MJ, Langin T (1994). Transposable elements in the fungal plant pathogen Fusarium oxysporum. Genetica 93(1-3):49-59.

Dinolfo MI, Castañares E, Stenglei SA (2014). Characterization of a Fusarium poae world-wide collection by using molecular markers. Eur. J. Plant Pathol. 140(1):119-132.

Dufresne M, Lespinet O, Daboussi M J, Hua-Van A (2011). GenomeWide Comparative Analysis ofpogo-Like Transposable Elements in Different Fusarium Species. J. Mol. Evol. 73(3-4):230-243.

Dunn IS, Blattner FR (1987). Charons 36 to 40: multienzyme, higt capacity, recobination deficient replacement vectors with polylinkers and polystuffers. Nucleic Acids Res. 15:2677-2698.

Fischer IH, Kimati H, Resende JAM (2005). Doenças do maracujazeiro (Passiflora spp.). In: Kimati H, Amorim L, Resende JAM, Bergamin Filho A, Camargo LEA (Eds). Manual de fitopatologia: doenças das plantas cultivadas. 4. ed. São Paulo: Agronômica Ceres. pp. 468474.

Gavlak AA, Prado BR, Barros MA (2013). Padrões de ocupação no
Pantanal brasileiro e sua dinâmica entre os nos de 2002 e 2008: sensoriamento remoto e mineração de dados espaciais aplicados à análise espaço-temporal do desmatamento. In: Simpósio Brasileiro de Sensoriamento Remoto, 16. (SBSR), Foz do Iguaçu. Anais... São José dos Campos: INPE, 2013. pp. 7064-7070.

IBGE - Instituto Brasileiro de Pesquisa e Estatística (2004). Mapas de Biomas do Brasil: escala 1:5.000.000. Available at: http://www.ibge.gov.br/home/presidencia/noticias/21052004biomasht ml.shtm.

IBGE - Instituto Brasileiro de Pesquisa e Estatística (2015). Produção Agrícola Municipal. Available at: http://www.ibge.gov.br/home/estatistica/economia/pam/2013/default.s htm.

Jaccard P (1908). Nouvelles recherches sur la distribution florale. De la Societé Vaudoise des Sciences Natureles 44:223-270.

Junk WJ, Cunha CN, Wantzen KM, Petermann P, Strüssmann C, Marques MI, Adis J (2006). Biodiversity and its conservation in the Pantanal of Mato Grosso, Braz. Aqua Sci. 69(3):278-309.

Leslie JF, Summerell BA (2006). The Fusarium Laboratory Manual. Blackwell Publishing, Ames, IA, USA. 388p.

Liberato JR, Costa H (2001) Doenças fúngicas, bacterianas e fitonematóides. In: Bruckner $\mathrm{CH}$, Picanço $\mathrm{MC}$ (Eds.) Maracujá: tecnologia de produção, pós-colheita, agroindústria, mercado. Porto Alegre RS. Cinco Continentes. pp. 243-245.

Longato S, Bonfante $P(1997)$. Molecular identification of mycorrhizal fungi by direct amplification of microsatellite regions. Mycol. Res. 101(4):425-432.

Marcuzzo FFN, Andrade LR, Melo DCR (2011). Métodos de Interpolação Matemática no Mapeamento de Chuvas do Estado do Mato Grosso. Revista Brasileira de Geografia Física 4(4):793-804.

Nash SM, Snyder WC (1962). Quantitative estimations by plate counts of propagules of the bean root rot Fusarium in field soils. Phytopathology 52:567-572.

Nelson PE, Toussoun TA, Marasas WFO (1983). Fusarium species: An Illustrated Manual for Identification. Pennsylvania State University Press, University Park. 193 p.

Nirenberg HI (1990). Recent advances in the taxonomy of Fusarium. J. Stud. Mycol. 32:91-101.

Pio-Ribeiro G, Mariano LR (1997). Doenças do maracujazeiro (Passiflora spp). In: Kimati H, Amorim L, Bergamim Filho A, Camargo LEA, Rezende JAM (Ed.). Manual de fitopatologia: doenças de plantas cultivadas. 3.ed. São Paulo: Agronômica Ceres. pp. 525-534.

Queiroz CB, Santana MF, Silva GF, Mizubuti ESG, Araújo EF, Queiroz MV (2014). Use of the IRAP Marker to Study Genetic Variability in Pseudocercospora fijiensis Populations. Curr. Microbiol. 68(3):358364

Santos LV, Queiroz MV, Santana MF, Soares MA, Barros EG, Araújo EF, Langin T (2012). Development of new molecular markers for the Colletotrichum genus using RetroCl1 sequences. World J. Microbiol. Biotechnol. 28(3):1087-1095.

Saxena A, Raghuwanshi R, Singh HB (2014). Molecular, phenotypic and pathogenic variability in Colletotrichum isolates of subtropical region in north-eastern India, causing fruit rot of chillies. J. Appl. Microbiol. 117(5):1422-1434.

Schmidt SM, Houterman PM, Schreiver I, Ma L, Amyotte S, Chellappan B, Boeren S, Takken FLW, Rep M (2013). MITEs in the promoters of effector genes allow prediction of novel virulence genes in Fusarium oxysporum. BMC Genomics 14:1-21.

Silva AS, Oliveira EO, Haddad F, Jesus ON, Oliveira SAS, Costa MAPC (2013). Molecular fingerprinting of Fusarium oxysporum f. sp. passiflorae isolates using AFLP markers. Sci. Agric. 70(2):108-115.

Waalwijk C, Keszthelyi A, van der Lee T, Jeney A, de Vries I, Kerenyi Z, Mendes O, Hornok L (2006). Mating type loci in Fusarium: structure and function. Mycotoxin Res. 22(1):54-60.

White TJ, Bruns T, Lee S, Taylor J (1990). Amplification and direct sequencing of fungal ribosomal RNA genes for phylogenetics. In: PCR protocols: a guide to methods and applications. pp. 315-322. 